\title{
O motywach podróży w literaturze frankofońskiej Maghrebu
}

\author{
Z Dr hab. Magdaleną Zdradą-Cok* \\ rozmawia Magdalena Lewicka
}

DOI: http://dx.doi.org/1 0.12775/LC.2019.014

Magdalena Lewicka: Ten tom poświęcony jest zjawisku podróży postrzeganej jako źródło inspiracji w literaturach Zachodu i arabskiego Orientu, a co za tym idzie zaproszeni przez nas do udziału we wspóltworzeniu go autorzy pochylają się nad fenomenem podróży, jednym z najczęściej bodaj spotykanych w kulturze motywów, do którego odwołują się twórcy słowa, sztuki i filmu. Autorzy zebranych tu tekstów kreślą szkice i analizy literackiej ekspresji służącej konstrukcji i rekonstrukcji toposu podróży, zarówno w rzeczywistym jej wymiarze, to jest wędrówki podejmowanej z takich czy innych powodów, w takich czy innych celach, bądź to dobrowolnej, bądź wymuszonej skazaniem na emigrację i tułaczkę wraz ze wszystkimi jej implikacjami, jak i wymiarze symbolicznym, metafizycznym, metaforycznym, tj. podróży w czasie lub przestrzeni prowadzącej do refleksji nad samym sobą i własnym losem w poszukiwaniu wartości doczesnego bytu i sensu ludzkiej egzystencji, bądź jako ucieczki od determinujących życie problemów, dylematów i wewnętrznych rozterek.

Magdalena Zdrada-Cok (dalej M.Z-C.): Rzeczywiście podróż jawi się jako najbardziej uniwersalny topos literacki. Jest sama w sobie symbolem osadzonej w czasoprzestrzeni egzystencji, która przecież opiera się na zmienności: począwszy od heraklitejskiej koncepcji panta rhei - życia jako ciągłego ruchu, stawania się, po bergsonowski pęd życiowy - élan vital. Podróż stanowi również metaforę pisarstwa: lektura jest swoistą podróżą w obrębie wyznaczonej czasoprzestrzeni fabuły, która otwiera się przed czytelnikiem. W kontekście literatury frankofońskiej podróż okazuje się szczególnie fascynująca. Nie tylko dlatego, że

Drnauk humanistycznych w zakresie literaturoznawstwa, adiunkt w Zakładzie Literatury i Kultury Francuskiej i Frankofońskiej Instytutu Języków Romańskich i Translatoryki na Wydziale Filologicznym Uniwersytetu Śląskiego. E-mail: cok@onet.pl. 
motyw ten związany jest z problematyką poszukiwań tożsamości pisarza. Nie tylko dlatego, że wiąże się z motywami, o których Pani Doktor wspomniała: wygnaniem, powrotem do korzeni, migracją i imigracją, poszukiwaniem wolności lub przynależności do danej wspólnoty, ale przede wszystkim dlatego, że mamy tu do czynienia z wędrówką niezwykłą. Język francuski jest bowiem środkiem do poznania kultur rozproszonych na pięciu kontynentach od Europy (Belgia, Szwajcaria, Luksemburg, itd.), Ameryki Północnej (Quebec), Antyli i wysp Oceanu Indyjskiego (Karaiby, Reunion, Mauritius), poprzez Afrykę Północną i Subsaharyjską aż po Bliski Wschód (Liban) i Półwysep Indochiński (Wietnam, Laos, Kambodża). Literatura staje się tu synonimem podróży, bez względu na to, czy czytelnik, wzorem mało dociekliwego turysty, będzie w niej poszukiwal potwierdzenia własnych wyobrażeń i egzotyki, czy może spróbuje odnaleźć w niej odpowiedzi na pytania dotyczące skomplikowanej rzeczywistości społeczno-politycznej obszarów frankofońskich, czy wreszcie, tak jak egzota Viktora Segalena, poszuka w niej klucza do zrozumienia siebie i Innego.

Motyw podróży stał się narzędziem, po które sięgali - w rozmaitych celach i różnorodnych formach reprezentujących wszystkie literackie gatunki i rodzaje - twórcy wszystkich epok, pod każdą szerokością geograficzną. Szczególnie często motyw ten pojawia się w przestrzeni frankofońskiej literatury Maghrebu, mocno osadzonej w historii Arabskiego Zachodu, a co za tym idzie silnie naznaczonej długoletnią kolonizacją i jej implikacjami społeczno-politycznymi, tak dla jednostek, jak i całych społeczności zamieszkujących Maroko, Algierię i Tunezję. Wyrastające na ich podłożu dylematy tożsamościowe, rozdarcie pomiędzy dwoma językami, dwiema kulturami, a nierzadko i dwiema ojczyznami, zostawiły trwały ślad zarówno w biografiach maghrebskich pisarzy, jak i w ich dziełach, nawiązujących do krwawych kart w historii ich krajów i podejmujących problematykę poszukiwania siebie i swojego miejsca. Zanim przejdziemy do problematyki podróży, chciałabym zapytać Panią Profesor, czy można przeprowadzić periodyzację głównych zjawisk procesu historycznoliterackiego w rozwoju francuskojęzycznego piśmiennictwa Maghrebu oraz wyodrębnić poszczególne jednostki dynamizujące jego przebieg w czasie? Opisać okresy i etapy literackie, prądy i nurty bądź przynajmniej trendy czy tendencje dla tych etapów charakterystyczne?

M.Z.-C.: Zdecydowanie tak, mamy bowiem tutaj do czynienia $\mathrm{z}$ trwającym od około siedemdziesięciu lat procesem historycznoliterackim. Odwołam się może do klasyfikacji literatury Maghrebu zaproponowanej przez Jacques'a Noiray. Badacz ten wprowadził trzy kryteria: według pokoleń literackich, według okresów literackich i według tematów. W pierwszej klasyfikacji Noiray wyróżnił pokolenie założycieli, następnie pokolenie 1970 oraz pokolenie lat 80 . Wśród założycieli wymienić należy wspomnianych już wcześniej pisarzy urodzonych około 1920 roku: w Maroku Ahmeda Sefrioui, w Tunezji Alberta Memmi, w Algierii Mohammeda Diba i Moulouda Mammeriego. Można zaliczyć do tego pokolenia urodzonych nieco później, ale debiutujących w tym samym okresie (lata 50.) pisarzy, takich jak: Driss Chraïbi, Malek Haddad i Kateb Yacine. To pokolenie Noiray uznaje za najbardziej klasyczne, które stworzyło dzieła najbardziej znane, najczęściej analizowane: Nedjma, Le fils du pauvre (Syn biedaka), La colline oubliée (Zapomniane wzgórze), La statue de sel (Solny posą), Le passé simple (Czas przeszły prosty). Z kolei pokolenie 1970 to pisarze urodzeni około 1940, którzy zadebiutowali pod koniec lat 60. i na początku lat 70 .: 
Algierczycy - Assia Djebar, Rachid Boudjedra, Nabile Farès, oraz Marokańczycy skupieni wokół czasopisma „Souffles” - Tahar Ben Jelloun Abdelkébir Khatibi, Mohammed KhaïrEddine, Abdellatif Laâbi. Twórczość tego pokolenia jest niezwykle ciekawa i ma fundamentalne znaczenie dla historii literatury maghrebskiej w języku francuskim. Z jednej strony pisarze rozwijają problematykę zapoczątkowaną przez poprzedników (poszukiwania tożsamościowe, krytyka społeczna, rozrachunek z przeszłością kolonialną). Z drugiej strony czynią to $w$ niezwykle oryginalnej formie, skupionej zarazem na eksperymencie oraz na związkach z arabsko-berberską literaturą oralną. Przeplatają formę poetycką przesiąkniętą duchem Maghrebu, ale również zainspirowaną symbolizmem i surrealizmem, z satyryczną prozą. Tworzą estetykę eklektyczną, a czasem wręcz hermetyczną. Podejmują temat buntu wobec skostniałych norm obyczajowych. Wpisują się zatem w tradycję Drissa Chraibiego, który jednak posługiwał się bardziej klasycznym dyskursem i realistycznym obrazowaniem. Pracując nad językiem, odnajdując jego bogactwo, otwartość na eksperyment w kontekście pluralizmu kulturowego i lingwistycznego, podążają ścieżką wytyczoną przez Kateba Yacina. Ich transgresyjna, prowokująca twórczość jest zarazem autobiograficzna i zbiorowa. Mohamed Ridha Bouguerra i Sabiha Bouguerra określą tych twórców mianem „pokolenia transgresji i rozbitych form”. Trzecie pokolenie, debiutujące w latach 80 ., rozwija problematykę społeczną i polityczną, a także w dalszym ciągu podejmuje wątki skomplikowanej tożsamości, ale czyni to za pomocą pisarstwa bardziej mimetycznego, realistycznego, opartego na prostszym języku. Ta klasyfikacja zdaje oczywiście sprawę z ogólnych tendencji i jako taka stanowi uproszczenie. Zauważyć bowiem trzeba, że w latach 80. i 90. zbuntowane drugie pokolenie powraca do prostszej formy wypowiedzi i porzuca eksperyment słowny na rzecz znacznie bardziej jednoznacznego dyskursu. Ta ewolucja jest niezwykle wyraźna np. u Tahara Ben Jellouna, Mohammeda Khaïra-Eddine’a i Abdelkébira Khatibiego.

Wspomniała Pani również podział literatury Maghrebu na okresy literackie oraz z punktu widzenia tematycznego. Co znajduje się w centrum zainteresowania twórczego pisarzy maghrebskich, po jakie sięgają motywy i jakie podejmują tematy poza wskazanym wyżej kolonializmem postrzeganym jako apokalipsa, z której wyłonił się nowy świat zdeterminowany koniecznością budowy od podstaw organizmów państwowych i tworzących je społeczności. Trudno przecenić znaczenie tych przemian jako osi, na której pisarze konstruowali fabułę swoich utworów, i układu odniesienia dla ich kreacji twórczych, z nich bowiem wypływa większość problemów nurtujących postkolonialny Maghreb. Czy można wskazać charakterystyczne dlań motywy i wątki tematyczne, nie tylko te tworzone na kanwie historycznego dziedzictwa kolonialnego, ale i te, które pisarze frankofońscy Arabskiego Zachodu dzielą z twórcami innych regionów i epok? Z jakich motywów komponują swoje obrazy, czy przechodzą od dylematów maghrebskich do uniwersalnych problemów reszty świata?

M.Z.-C.: W podziale na okresy literackie Noiray wyróżnia pierwsze dziesięciolecie (1945-1954), gdy powstała literatura koncentruje się na procesie dekolonizacji, przedstawia obraz społeczeństwa zdominowanego, ujawnia represyjność władzy kolonialnej oraz wyraża budzącą się świadomość narodową. Jeśli powstają w tym czasie teksy poświęcone krytyce społeczeństwa oraz rodziny, nie są one przyjęte z należytym zrozumieniem (ma to miejsce w przypadku Le passé simple [Czas przyszły prosty] Drissa Chraibiego). W drugim okresie, tj. w latach 1954-1968, uwaga skoncentrowana jest na dążeniach nie- 
podległościowych i przede wszystkim sytuacji Algierii pogrążonej w krwawej wojnie. To epoka wielkich powieści wojennych: Les enfants du nouveau monde (Dzieci z nowego świata, 1962) Assi Djebar, Qui se souvient de la mer (Kto pamięta o morzu, 1962) Mohameda Diba. W trzecim okresie (1968-1980) dominować zacznie krytyka skostniałego społeczeństwa patriarchalnego, pokolenie transgresji podejmie tematy alienacji, wolności jednostki, indywidualizmu, złożonej tożsamości. A co najważniejsze, idąc tropem Kateba Yacine'a, wypracuje oryginalne paradygmaty stylistyczne oraz stworzy hybrydyczną estetykę zainspirowaną równocześnie wieloma tradycjami, jak i poszukiwaniem eksperymentalnych, nowych form.

Jeśli chodzi o wspomnianą klasyfikację tematyczną, w pierwszym okresie rozwoju tychże literatur dominowały tematy związane z przeszłością kolonialną i z dekolonizacją: rozrachunek z kolonizatorem, poczucie krzywdy, alienacji, wydziedziczenia skolonizowanego, wyzyski ekonomiczny i niesprawiedliwość. Autorzy tacy jak: Mohamed Dib ( La grande maison [Wielki dom], L'Incendie [Pożar]), Mouloud Mammeri (Le Sommeil du juste [Sen sprawiedliwego]), Kateb Yacine (Nedjma) powracają do historii kolonizacji i odbudowują poczucie narodowej tożsamości i kulturowego samostanowienienia, co oczywiście nie jest łatwe, w sytuacji dysglosji, gdy decydują się zmierzyć z bolesną przyszłością i trudną współczesnością w języku kolonizatora. Wojna francusko-algierska obecna jest w prozie, teatrze i poezji m.in. Mohameda Diba, Kateba Yacina i Assii Djebar.

Drugim, ogromnym obszarem zainteresowania pisarzy maghrebskich jest społeczeństwo z jego złożoną strukturą, fascynującą kulturą i licznymi napięciami. Od lat 70. ważne jest zaangażowanie społeczne pisarzy, misja „pisarzy publicznych” (zdefiniowana przez Tahara Ben Jellouna) piętnujących zacofanie, analfabetyzm, biedę, broniących praw człowieka, domagających się modernizacji i postępu we wszystkich dziedzinach życia. Pisarze tacy jak: Driss Chraibi (Le passé simple [Czas przeszły prosty], Civilisation, ma mère! [Przebudź się, matko!]), Rachid Boudjedra (La Répudiation [Oddalenie]), Tahar Ben Jelloun (Harrouda, Moha le fou, Moha le sage [Moha szaleniec, Moha mędrzec]), Abdelhak Serhane (Messauda) zaprezentowali bardzo krytyczny ogląd tradycyjnego modelu rodziny, wskazali na konieczność zmiany sytuacji kobiety i dziecka, dokonali kontestacji patriarchatu (a wraz z nim islamu postrzeganego jako źródła konserwatywnych wartości).

Krytyka społeczno-politycznej rzeczywistości nasiliła się w kontekście różnych napięć: w czasie „ołowianych lat” w Maroku wielu pisarzy pokolenia transgresji opisało wydarzenia marca '65, pojawiły się ostre głosy sprzeciwu wobec reakcyjnej polityki Hassana II, represji generała Oufkira, arabizacji kraju. Wielu intelektualistów zmuszonych zostało do emigracji (Tahar Ben Jelloun, Abdelkébir Khatibi), inni zostali poddani represjom i skazani na wieloletnie kary więzienia (Abdellatif Laâbi, założyciel lewicowego czasopisma spędził osiem lat w więzieniu w Kenitrze w latach 1972-1980). Obecnie te wydarzenia powracają w szeroko reprezentowanej literaturze więziennej. Wspomnę chociażby powieść Cette aveuglante absence de lumière (To oślepiające nieobecne światło) Tahara Ben Jellouna, A l'ombre de Lalla Chafia (W cieniu Lalli Chafii) Drissa Buissefa Rekaba, Le Couloir (Korytarz) Abdelfettaha Fatihani czy La chambre noire (Czarny pokój) Jaouada Mdidecha.

W Algierii zaangażowanie pisarzy w sprawy kraju nabrało szczególnie dramatycznych rysów w kontekście wojny domowej w latach 90. (Tahar Djaout umarł bestialsko 
zamordowany w 1993, twórca teatralny Abdelkader Alloula poniósł śmierć z rąk terrorystów islamskich w 1994), a wielu intelektualistów znalazło azyl polityczny we Francji (Mohamed Kacimi, Rachid Mimouni). Wydarzenia tego krwawego dziesięciolecia powrócily na kartach utworów Bualema Sansala (Le Serment des Barbares [Przysięga Barbarzyńców]), Assii Djebar (Oran, langue morte [Oran, martwy język], Le Blanc de l’Algérie [Biel Algierii]), Mohameda Kacimi (Le jugement dernier [Sąd ostateczny], Confession d'Abraham [Spowiedź Abrahama])..

Stwierdzić zatem możemy, że na żadnym z etapów swojej historii francuskojęzyczna proza maghrebska nie odwróciła się od problemów politycznych i społecznych.

M.Z.-C.: Istotnie, przepojona humanizmem, niezgodą wobec okrucieństwa, broni godności ludzkiej, wyraża uniwersalne wartości, takie jak prawo człowieka do wolności, samostanowienia. Twórcy z Maghrebu komentują zatem wydarzenia arabskiej wiosny: natychmiast po bulwersującym akcie samospalenia Mohameda Bouazzizi, mającym miejsce 17 grudnia 2010 roku, Tahar Ben Jelloun opublikował opowiadanie Par le feu (W ogniu), przywołując historię tego młodego sprzedawcy owoców z Tunisu, którego samobójstwo zapoczątkowało wydarzenia „jaśminowej rewolucji”. Pisarze starają się uwrażliwić opinię publiczną na problem masowych tragedii nielegalnych afrykańskich imigrantów. Powstają przejmujące powieści, takie jak: Les Clandestins (Nielegalni imigranci) Youssoufa Amine’a Elalamy, Cannibales (Ludożercy) Mahi Binebine’a, Harraga Bualema Sansala, Tu ne traverseras pas le détroit (Nie przepłyniesz cieśniny) Salima Jay.

Powieści te kontynuują wątek imigracyjny obecny we francuskojęzycznej prozie Algierii, Maroka i Tunezji od jej narodzin. Przypomnę, że za pierwszą emigracyjną powieść uznaje się Les Boucs (Kozły ofiarne) Drissa Chraïbiego z 1955 roku, a wśród autorów szczególnie zainteresowanych życiem diaspory wymienić należy Moulouda Feraouna (Le fils du pauvre [Syn biedaka], Les chemins qui montent [Drogi pod górę]), Kateba Yacina (Le polygone étoilé [Rozgwieżdżony poligon]), Tahara Ben Jellouna (La Réclusion solitaire [Zamknięcie w samotności], Les yeux baissés [Spuszczony wzrok], Partir [Wyjechać], Au Pays [W kraju]). Ciekawym zjawiskiem związanym ze światem imigracji jest literatura drugiego pokolenia imigracyjnego, tzw. literatura „beur” reprezentowana m.in. przez Leilę Sebbar (Shérazade 17 ans, brune, frisée, les yeux verts [Szeherazada, 17 lat, ciemne kręcone włosy, zielone oczy], Fatima ou Les Algériennes au square [Fatima czyli Algierki na skwerze]), Meddhi Charefa i Azouza Begaga.

W twórczości diaspory odnajdujemy wspólne dla literatur postkolonialnych tematy, takie jak: podwójna kultura, konflikt pokoleń, konflikt tradycji i nowoczesności, wygnanie, problematyczny powrót do korzeni, poszukiwanie tożsamości, konfrontacja z rasizmem i stereotypami kulturowymi, alienacja i egzotyzacja ,ja”. Te wszechobecne w literaturach postkolonialnych kwestie stanowią główną oś tematyczną utworów o inspiracji osobistej, autobiograficznej. Pisarze - tacy jak Khatibi, Ben Jelloun, Kacimi, Djebar - łączą wymiar autobiograficzny z metaliterackim (dzielą się z czytelnikiem swoimi refleksjami na temat poszukiwań formalnych, stylistycznych i językowych). Równocześnie nie przestają wyznaczać sobie swoistych misji społecznych, ich wielopłaszczyznowe teksty nie wpadają w pułapkę formalizmu czy metafikcji. Ich twórczość, chociaż niełatwa w odbiorze (który powinien odbywać się na wielu poziomach) bez wątpienia dotyka najbardziej uniwersalnych pytań, które współcześnie zadaje sobie twórca literatury. 
Po odzyskaniu niepodległości przez kraje Maghrebu środowisko twórców tego regionu wykorzystujących język francuski jako narzędzie swojego pisarstwa stanęło przed istotnym dylematem - kontynuowania działalności literackiej w mowie byłego kolonizatora bądź porzucenie jej na rzecz mother language, by odciąć się od historycznego dziedzictwa imperializmu i politycznej dominacji Francji. To sprawiło, że część intelektualistów zapowiadała rychłe zniknięcie frankofońskiej literatury Arabskiego Zachodu. Tak się jednak nie stało, maghrebscy pisarze nie tylko nie odeszli od la langue française, lecz nawet więcej - uznali dziedzictwo kultury francuskiej, wraz ze związanym z nią ściśle językiem, za element przeszłości i teraźniejszości Maghrebu. W ten sposób wielowymiarowość spuścizny kulturowej i językowej stała się jedną z cech ich pisarstwa i odwrotnie - pisarstwo stało się przestrzenią wyrażania owej wielowymiarowości.

M.Z.-C.: Istotnie, wątki związane z kolonializmem oraz jego konsekwencjami wpisane są w genezę francuskojęzycznej literatury Maghrebu. W szerszym aspekcie skutki różnych podbojów na przestrzeni wieków - podboje rzymskie, ekspansja arabska w czasach dominacji kultury berberskiej, wreszcie okres dominacji francuskiej (i częściowo również hiszpańskiej), a w pokojowym wymiarze obecność kultury żydowskiej (koegzystencja arabskiej medyny z żydowskim mellahem) - pozostawiły trwałe ślady w kulturze maghrebskiej i zainspirowały literaturę frankofońską. W zdekolonizowanych państwach język francuski stał się środkiem, by po pierwsze tę wielokulturową spuściznę przedstawić w dyskursie literackim, po drugie, by usytuować tę refleksję w szerszym, frankofońskim, postkolonialnym kontekście: tzn. odkryć analogie pomiędzy kulturą maghrebską i innymi kulturami (np. antylską czy argentyńską). Khatibi i Ben Jelloun odnaleźli w kosmopolitycznej i uniwersalnej twórczości Borgesa zafascynowanego Baśniami tysiąca $i$ jednej nocy pewną wrażliwość niezwykle im bliską, wywiedzioną z rodzimej orientalnej tradycji. Z jednej strony literatura frankofońska zakorzeniona jest $\mathrm{w}$ tradycji maghrebskiej, z drugiej zaś jest swoistym pomostem pomiędzy tą tradycją i innymi kulturami. Doskonale przedstawił to Abdelkébir Khatibi w dwóch pracach z pogranicza kulturoznawstwa i socjologii Penser le Maghreb (Przemyśleć Maghreb) i Maghreb pluriel (Pluralny Maghreb). Opisał złożoną tożsamość kulturową i językową tego rozdartego pomiędzy Afryką, Europą i Bliskim Wschodem obszaru, charakteryzującego się bogactwem dialektów arabskich i berberskich, licznymi związkami z Francją i Hiszpanią, przesiąkniętego tradycyjną kulturą ludową, otwartego na wzorce kultury europejskiej. Bez wątpienia dziedzictwo kultury arabsko-muzułmańskiej jest dominującym elementem kultury Maghrebu, która jednak mieni się różnorodnością odcieni i niuansów wynikłych ze związków ze światem chrześcijaństwa, judaizmu, z obecności rdzennej kultury berberskiej oraz z kontaktu z laickimi tradycjami republiki francuskiej. W duchu postkolonialnym i postmodernistycznym Khatibi dokonał pochwały peryferyczności Maghrebu, leżącego poza wielkimi źródłami dominujących kultur i religii, ale pozostającym pod ich wpływem. Ten wielokulturowy, mozaikowy charakter świata maghrebskiego sprawia, że refleksja intelektualistów w okresie postkolonialnym posiada wspólne płaszczyzny z zainspirowaną peryferiami, różnorodnością, zmiennością filozofią postmodernistyczną Jacques'a Derridy (notabene związanego z Algierą oraz z kulturą judaistyczną) i Gilles’a Deleuze’a i Félixa Guattariego (teoria kłącza: rhizome). 
Jak odzwierciedla się to $w$ warstwie językowej, figurach stylistycznych, gramatyce, narracji? Jak twórcy eksperymentują z tworzywem literackim?

M.Z.-C.: Dla francuskojęzycznej literatury Maghrebu znamienne są m.in. takie zjawiska, jak: interakcja gatunków i form prowadząca do powstania dzieł z pogranicza różnych gatunków, bądź tzw. gatunków mieszanych, które nie poddają się „czystej” europejskiej klasyfikacji; intertekstualność osadzająca się na włączaniu do dzieł własnych refleksji autorów reprezentujących piśmiennictwo Zachodu i Wschodu; aspekt autobiograficzny, przy czym nawet jeśli twórcy nie nadają swym bohaterom własnego imienia, czytelnik nie ma wątpliwości, że bohaterowie ci pozostają rzecznikami w opowiadaniu o ich własnym życiu i naznaczających je dylematach; wreszcie - swoista polifonia przejawiająca się w interferencji językowej, to jest mieszaniu kodów językowych, wykorzystaniu różnorodnych rejestrów języka. Ponadto pisarze maghrebscy ukazują ogromny potencjał drzemiący w rodzimej kulturze oralnej. Ale to naturalne zainteresowanie tradycjami ustnymi często łączą z fascynacją innymi sztukami: teatrem (Kateb, Djebar, Kacimi, Ben Jelloun), sztukami plastycznymi (Boudjedra, Djebar, Sebbar, Ben Jelloun, Kacimi), filmem (Djebar, Sebbar). Odnieść można wrażenie, że pisarstwo jest przede wszystkim doświadczeniem wolności, niczym nieskrępowaną podróżą poprzez różne dziedziny kultury, nieustannym spotkaniem z Innym. W niezwykle piękny sposób pisze o tym Tahar Ben Jelloun, który w najnowszych tekstach z pogranicza autobiografii, biografii i fikcji przedstawia swoje realne i mentalne spotkania z Genetem, Beckettem, Le Clézio, Matissem, Delacroix, Giacomettim i wieloma innymi artystami. Twórczość staje się dla autora Harroudy ciąglym przekraczaniem granic między sobą i Innym, procesem, w którym indywidualizm i egocentryzm porzucone są na rzecz dialogu i otwartości.

Ten wielokulturowy wymiar twórczości jest znamienny również dla Assi Djebar. Powieści Djebar, oparte na jej własnych przeżyciach, zdeterminowane są dziejami jej ojczyzny, a zarazem naznaczone swoistym „zawieszeniem” pomiędzy kulturą Wschodu i Zachodu. Jak wyglądała artystyczna droga Assi Djebar, która doprowadziła ją do Akademii Francuskiej jako jedyną pisarkę z krajów Maghrebu?

M.Z.-C.: Assia Djebar, czyli Fatima-Zohra Imalayène, wywodziła się z rodziny drobnomieszczańskiej. Dla jej ojca, nauczyciela języka francuskiego, ważna była kwestia edukacji córki: Assia Djebar w ciągu całej swojej kariery pisarskiej i akademickiej miała świadomość tego „uprzywilejowania”, które szczególnie zmotywowało ją do obrony sprawy kobiet pozbawionych prawa do wolności i samostanowienia. Po okresie edukacji w szkole francuskiej i w prywatnej szkole koranicznej, Assia Djebar ukończyła, jako pierwsza muzulmańska kobieta, prestiżową Ecole Normale Supérieure w Sèvres, specjalizując się w historii nowożytnego i współczesnego Maghrebu. Poparła wówczas walczących o niepodległość Algierczyków, za co w 1958 roku została wydalona ze szkoły. Przywrócono jej prawa studenta za sprawą generała Charles'a de Gaulle’a, który docenił jej talent literacki. Assia Djebar miała już wtedy na swoim koncie debiut literacki: porównywaną z utworami Françoise Sagan powieść La Soif (Pragnienie) wydaną w 1957 roku. Prawdziwy punkt wyjścia jej artystycznej drogi stanowią jednak poświęcone wojnie o niepodległość Algierii powieści Les enfants du nouveau monde (Dzieci z nowego świata, 1962) i Les alouettes naïves (Naiwne jaskółki, 1967), w których autorka wyraża sprzeciw wobec „niewidzialności”, na którą skazane są kobiety w społeczeństwie muzułmańskim. W kolejnych wielotematycznych, poli- 
fonicznych utworach Femmes d'Alger dans leur appartement (Algierskie kobiety w swoim pokoju, 1980), L'amour, la fantasia (Fantazja miłosna, 1985), Ombre sultane (Sułtański cień, 1987), Vaste est la prison (Rozległe jest moje więzienie, 1995) pisarka ukazuje losy kobiet z perspektywy historycznej (pochylając się nad kolonizacją Algierii) i współczesnej, zarazem indywidualnej (oraz intymnej) i zbiorowej. Dialog z Delacroix i Picasso we wspomnianym utworze z 1980 roku to nie tylko pretekst, by zilustrować problem uprzedmiotowienia kobiecego ciała. Refleksja ta staje się punktem wyjścia do rozważań na temat dominacji kolonialnej, opresji, kulturowej kategorii Inności i związanych z nią orientalistycznych uproszczeń. Assia Djebar oddaje hołd kobiecie muzułmańskiej, która pojawia się w jej bogatym dziele w najrozmaitszych wcieleniach: zapomnianej bohaterki wojny o niepodległość w La femme sans sepulture (Kobieta bez pochówku), czy szefowej, prorokini, królowej w powieści Loin de Médine (Daleko od Medyny), której akcja toczy się w Medynie po śmierci Proroka. Kobieta jest w twórczości Assi Djebar nie tylko istotą ignorowaną, upokarzaną, „niewidzialną". Często jest osobą zaangażowaną, walczącą, solidarną z członkami swojej społeczności, poszukującą wolności. Przywołując w ten pobieżny, skrótowy sposób twórczość pierwszej członkini Akademii Francuskiej pochodzącej z Afryki Północnej, wspomnę jeszcze, że mamy tu do czynienia z tekstami wielowymiarowymi: erudycyjnymi, zaangażowanymi moralnie i społecznie. W Oran, langue morte (Oran, martwy język), Le Blanc de l'Algérie (Biel Algierii) Djebar opisuje dramatyczne losy kompatriotów w okresie wojny domowej. Przestrzeń jej pisarstwa to przestrzeń, w której dokonuje się nieustanny proces wyzwolenia kobiet. To również przestrzeń, w której dochodzi do spotkania wielu kultur i w której ciągle krzyżują się różne języki. Francuski, który (chociaż wzbudza ambiwalentne emocje jako język dominacji i Inności) staje się, pod wpływem twórczej „obróbki”, językiem wolności i indywidualności. Arabski i berberski z kolei to języki przepojone muzykalnością i oralnością, za pomocą których Djebar składa hołd zmysłowości kobiecej i odnajduje własną, kobiecą tożsamość.

Podkreślmy zatem, że polifonia nabiera szczególnego wymiaru w perspektywie twórczości Assi Djebar, której tożsamość językowa oscyluje wokół dialektu berberyjskiego, używanego $\mathrm{w}$ kontaktach $\mathrm{z}$ dziadkami od strony matki, arabszczyzny, którą posługiwała się $w$ domu rodzinnym, oraz wykładanego $w$ szkole języka francuskiego, silnie powiązanego z osobą jej ojca. W tym kontekście niezwykle istotny jest fakt, że francuski pojawia się w jej dziełach jako język Innego, co zdaje się oznaczać manifestację tożsamości Djebar, arabskiej i francuskiej zarazem, przy czym tę ostatnią realizuje poprzez pisarstwo. Francuski budzi uczucia skrajnie różne: $z$ jednej strony nie jest językiem ojczystym, co więcej, jest mową kolonizatorów, a co za tym idzie krwawych kart w historii Algierii, z drugiej zaś został nabyty pod okiem ojca, osoby najbliższej i szczególnej w życiu pisarki, co sprawia, że doświadczany jest w kontekście dwóch światów, całkowicie ze sobą sprzecznych. Dwóch światów, które wyrażają zarazem odosobnienie i wyzwolenie, przekroczenie wymiarów kulturowego i spolecznego, związanych ze sferą intymną i zbiorową. Pisanie w mowie Innego jest niczym innym jak wygnaniem, ale wygnaniem $\mathrm{z}$ wyboru, zaś język postrzegany jest jako wyraz problemu tożsamościowego, który wpisuje się w aspekt dialektyczny między Sobą a Innym. Taka relacja, którą można określić mianem konfliktowej bądź pełnej sprzeczności, przedstawia się poprzez twórczość, będącą niczym innym, jak owym 
Sobą poprzez pryzmat Innego. Dzieła Djebar w języku określanym mianem języka Innego stają się zatem także obszarem powiązań między Francją i Algierią, dlatego też dla samej pisarki język, zarówno francuski, jak i arabski oraz berberski, stanowi o jej wrażliwości. Relacja, jaka istnieje w jej twórczości, pomiędzy Orientem i Zachodem wyraża się często poprzez zestawienie Ja i Innego. Djebar, aby podkreślić znaczenie tej opozycji, używa w swoich powieściach typizacji etnicznej odnoszącej się zarówno do swojej tożsamości francuskiej, jak i arabskiej. Jest to jednocześnie poszukiwanie Siebie, obejmujące zarówno język, jak i przestrzeń. Czy poszukiwanie to dzieli z innymi twórcami frankofońskiej literatury Maghrebu?

M.Z.-C.: Mówiąc o polifonii, dotykamy istoty francuskojęzycznej literatury maghrebskiej, która opiera się - jak wiemy - na świadomym akcie wyboru języka francuskiego jako języka wypowiedzi literackiej w sytuacji, gdy pisarz dysponuje innymi językami: arabskim klasycznym oraz dialektami arabskimi i berberskimi. Ten wybór, który determinuje twórczość maghrebskiego pisarza, implikuje szereg pytań, nie tylko, które on sam musi sobie postawić, ale również które napływają z zewnątrz. Często pytania te przybierają formę zarzutów, pretensji ze strony środowisk konserwatywnych i nacjonalistycznych. Te krytyczne nastroje były szczególnie żywe w okresie dekolonizacji, użycie języka kolonizatora wzbudzało wówczas spore kontrowersje w wielu środowiskach. Konfrontując się z własną wielojęzycznością, pisarz maghrebski odkrywa, definiuje, czasem tworzy własną tożsamość, która jest tożsamością hybrydyczną. Użycie języka Innego, w którym jednak pobrzmiewają inne języki, jest aktem, który pociąga za sobą rozmaite konsekwencje. Dla niektórych pisarzy jest ono źródłem wewnętrznych konfliktów, rozdarcia, poczucia winy. Te negatywne uczucia wzmacniane są przez fakt, że relacja pomiędzy językiem kolonizatora i językiem skolonizowanego opiera się na nierówności, dysglosji. Przypomnę raz jeszcze „dramat językowy” opisany przez Alberta Memmiego jako skutek akulturacji w Portrait du colonisé (Portret skolonizowanego). Kateb Yacine określił porzucenie języka ojczystego jako alienację i wewnętrzne wygnanie. Uznał język francuski za „łup wojenny”. Wprowadził do teatru arabski dialektalny. Motywowany podobnymi odczuciami Rachid Boudjedra zrezygnował z pisania w języku francuskim na rzecz arabskiego. Nie zapominajmy jednak, że w przypadku wielu pisarzy maghrebskich wybór języka francuskiego nie pociąga za sobą cierpienia, ale jest źródłem twórczej radości i satysfakcji. Tahar Ben Jelloun, podobnie jak Abdelkébir Khatibi są piewcami wielojęzyczności: nie porzucają dialektu arabskiego, wzbogacają nim własną francuszczyznę i wyrażają poprzez własną twórczość pochwałę hybrydycznej tożsamości zarówno językowej, jak i kulturowej. W tym przypadku język staje się pomostem między kulturami, czasem - co widać w najnowszych tekstach Ben Jellouna - środkiem promocji własnej kultury oraz podstawą fascynującego dialogu z Innym. Można zatem stwierdzić, że literatura maghrebska w języku francuskim jest przestrzenią, w której nieprzerwanie dokonuje się podróż. Język stanowi tu swoisty „środek transportu”. Pisarze z kolei odbywają niezliczone wędrówki w głąb własnej złożonej tożsamości. Assia Djebar odkrywa poprzez język francuski własną, arabską kobiecą wrażliwość, Mohamed Kacimi „pisze w samym sobie”. Podróż, która niejako dokonuje się „w języku francuskim”, jest w przypadku Kacimiego drogą do wolności, poszukiwaniem indywidualności. Niekiedy te literackie podróże maghrebskich pisarzy - zwłaszcza algierskich intelektualistów w epoce wojny domowej - noszą znamiona wygnania: artyści zmuszeni są opuścić kraj zdominowany przez przemoc i wojnę domową. Niejednokrotnie celem podróży jest spotkanie z Innym: czasem burzliwe, pełne 
niechęci, obrzmiałe ranami zadanymi przez Historię, czasem twórcze, oparte na dialogu i fascynacji Innym. Ten wątek jest bardzo obecny w biograficznych i autobiograficznych utworach Ben Jellouna, który odnajduje Inność w sobie, a siebie w Innym. Wreszcie podróż jest synonimem powrotu do korzeni: Leila Sebbar, nie znając języka arabskiego - języka ojca, będzie powracać do kultury arabskiej poprzez twórczość w języku francuskim.

Osadzając nasze rozważania w kontekście motywu podróży, nie sposób nie przywołać dzieła, w którym epos ten ujawnia się szczególnie silnie, i to zarówno przez pryzmat wędrówki realnej, emigracji, jak i tej metaforycznej, co sprawia, że analizowana jest $\mathrm{w}$ perspektywie powieści odysejskiej: La disparition de la langue française (Zniknięcie języka francuskiego) Assi Djebar...

M.Z.-C.: Tak, głównym bohaterem powieści jest Bekane, 45-letni algierski imigrant, który, po bolesnym rozstaniu z towarzyszką życia Marise, decyduje się powrócić do ojczystego kraju w latach 90. Berkane ma nadzieję odnaleźć kraj, którego obraz zachował w pamięci: z jego barwami, zapachami i językiem arabskim porzuconym w dzieciństwie. Zamierza również napisać powieść. Rzeczywistość, którą zastanie w Algierii, nie będzie zgodna z jego wyobrażeniami. Berkane odkryje kraj pogrążony w strachu i przemocy, zdominowany przez fundamentalizm, poddany arabizacji. Narracja „rozdarta” pomiędzy pierwszą i trzecią osobą skonstruowana jest w powieści m.in. wokół wątku korespondencji z Marise, spotkaniami z sąsiadem - rybakiem Rachidem i relacją z Nadjią.

Wracając do tytułu powieści: La disparition de la langue française (Zniknięcie języka francuskiego), jak się wydaje, już sam tenże tytuł przybiera charakter głównego paratekstu wyrażonego $\mathrm{w}$ jego symbolicznej i referencyjnej funkcji.

M.Z.-C.: Owszem, rodzajnik określony la podkreśla, że elementem centralnym powieści jest disparition, czyli „zniknięcie”. Z jednej strony może oznaczać zniknięcie głównego bohatera, jego ponowne wygnanie lub też śmierć, przy czym obie te możliwości są prawdopodobne, gdyż narrator nie wskazuje jego dalszych losów, z drugiej jednak - dalsza część tytułu implikuje zniknięcie języka francuskiego. Może to oznaczać, również w kontekście losów bohatera, brak możliwości odnalezienia swojej tożsamości związanej z językiem francuskim. Disparition, zniknięcie, wyraża zarówno miejsce, czyli ojczyznę, jak i żal oraz tęsknotę, innymi słowy mówiąc - nawiązuje do Algierii, gdzie Berkane nie może odnaleźć bezpośredniego kontaktu z językiem francuskim ze względu na nasilającą się arabizację kraju. Powrót bohatera w tak trudnym momencie historycznym dla jego ojczyzny nie pozostaje więc bez znaczenia, jest to bowiem okres powrotu języka arabskiego i próby przywrócenia mu pozycji odebranej przez język francuski. Disparition jako „zniknięcie” może odnosić się nie tylko do domniemanej śmierci lub wyjazdu Berkane'a, ale także - wbrew pozorom do jego powrotu do ojczyzny. Wszak najpierw na swój sposób znika z Algierii, opuszcza ją i wyjeżdża do Francji, a następnie jego wędrówka kończy się poprzez ponowne zniknięcie po powrocie do tego samego miejsca.

Pytanie, jakie nasuwa się w tym kontekście, dotyczy powodu zniknięcia bohatera. Czy zniknąl, ponieważ podjął próbę znalezienia swego rodzaju „złotego środka”, który pozwoliłby na połączenie dwóch części jego jestestwa, algierskiej i francuskiej, czy też dlatego, że nie potrafil stawić czoła przeszłości, tak odmiennej w jego wspo- 
mnieniach od tego, co zastał w kraju ojczystym? Wydawać by się mogło, że zniknięcie jest przede wszystkim porażką Berkane’a, która wynika z braku możliwości koegzystowania tych dwóch, jakże odmiennych, światów, tradycji i kultur. Niemniej jednak jego zniknięcie postrzegać można także jako formę odrodzenia, bowiem język francuski, który znika, staje się symbolem wolności, choć okres krwawej kolonizacji francuskiej został zastąpiony przez swego rodzaju „kolonizację” Algierii przez samych Algierczyków.

M.Z.-C.: Z całą pewnością dzieło Djebar prezentuje czytelnikowi rzeczywistość algierską, rzeczywistość, w jakiej znalazł się główny bohater. Na pierwszy plan wysuwa się chęć usunięcia barier pomiędzy tym, co jest francuskie, a tym, co algierskie. Berkane, powracając do ojczyzny, jest rozdarty pomiędzy Francją i Algierią, pomiędzy Francuzką a Algierką. Obcość, jaka ogarnia bohatera już na początku powieści, wynika z niemożności odnalezienia się we własnej ojczyźnie. Kraj, w którym żyje, nie jest bowiem ani Francją, ani Algierią, którą zachował w pamięci, co wyzwala w nim uczucie obcości, a zarazem wrażenie wygnania we własnej ojczyźnie. Uczucie tęsknoty, które jest mu tak bliskie, wynika z jego przywiązania do Francuzki, kobiety będącej ucieleśnieniem tego, co obce, i stanowiącej tego Innego, którego mu brak. Staje się to przyczyną wyobcowania, bowiem ów Inny wydaje się niezbędnym elementem $J a$ i powoduje, że samotność Berkane’a, który znalazł się pomiędzy dwiema kobietami, a tym samym między dwoma językami, dwiema kulturami i ojczyznami, pomiędzy Tu i Tam, prowadzi go nie tylko do pisarstwa, ale przede wszystkim do zachwiania tożsamości i tułaczki.

Czy podobnie ksztaltują się i funkcjonują w maghrebskim piśmiennictwie innych autorów francuskojęzycznych literackie realizacje motywu podróży?

M.Z.-C.: Tak, we frankofońskiej literaturze Maghrebu podróż najczęściej związana jest z tematem poszukiwań tożsamości. Łączy się z motywem wygnania, emigracji, powrotu do korzeni. Nierzadko ma wymiar autobiograficzny. Bywa też solidnie osadzona w realiach społecznych, zwłaszcza w nacechowanej socjologicznie powieści imigracyjnej. Często pojawia się jako oś tematyczna, wokół której pisarze organizują refleksje na temat historii swoich ojczyzn.

\section{W jaki sposób wątki autobiograficzne wiążą się z motywem podróży?}

M.Z.-C.: Autobiograficzny aspekt motywu podróży jest silnie obecny w twórczości Tahara Ben Jellouna. Historie opowiedziane w utworach Harrouda, L'Ecrivain public (Pisarz publiczny), Le Dernier ami (Ostatni przyjaciel) odwołują się do znaczącej w biografii pisarza przeprowadzki z Fezu do Tangeru. Ta podróż obarczona zostaje wieloma znaczeniami symbolicznymi. Staje się metaforą, wokół której pisarz snuje wątek związany z własnym dorastaniem i poszukiwaniem drogi twórczej w kraju pełnym sprzeczności. Porównanie Fezu i Tangeru to metafora ścierania się tradycji z nowoczesnością, nacjonalizmu z kosmopolityzmem, konserwatyzmu z buntem wobec patriarchatu. Dla autora Dziecka piasku podróż stanowi również metaforę pisarstwa. W wielowątkowej, barokowej, surrealistycznej powieści L’Auberge des pauvres (Oberża biedaków) z 1999 roku, inspirowanej filmem Felliniego, Tahar Ben Jelloun przedstawia historię pisarza, który opuszcza rodzinne Maroko i wyjeżdża do Neapolu, aby stworzyć utwór na temat tego miasta. W duchu marzy jednak, aby stać się marokańskim Joyce’em i stworzyć własną wersję Ulissesa! W Neapolu musi zmierzyć się 
z onirycznym, podziemnym światem, który odzwierciedla jego frustracje i niepokoje. Jest zdeformowanym obrazem rzeczywistości marokańskiej, jak również refleksem jego własnej podświadomości. Satyryczna, groteskowa powieść Ben Jellouna, interesująca szczególnie w warstwie metaliterackiej i intertekstualnej, jest swoistą mise en abyme pisarstwa.

Jak silny jest wkład frankofońskiej literatury Maghrebu w światowe piśmiennictwo francuskojęzyczne?

M.Z.-C.: Bez wątpienia Assia Djebar, Tahar Ben Jelloun czy Amin Maalouf (francusko-libański pisarz, członek Akademii Francuskiej od 2011 roku) należą do czołówki literatury światowej. Dziecko piasku i Święta noc, za którą Tahar Ben Jelloun otrzymał Nagrodę Goncourtów w 1987 roku, zostały przetłumaczone na czterdzieści trzy języki, a powieści członkini Akademii Francuskiej, Assi Djebar, przełożono na dwadzieścia trzy języki! Popularność w świecie tych uznanych we Francji twórców (Tahar Ben Jelloun jest członkiem dziesięcioosobowej prestiżowej Akademii Goncourtów od 2008 roku) ciągle wzrasta. Coraz większe grono czytelników sięga po książki zaangażowanych w walkę z terroryzmem i fundamentalizmem uznanych w świecie pisarzy, takich jak Boualem Sansal i Kamel Daoud, nie słabnie popularność Yasminy Khadry. Obserwujemy również wzrost zainteresowania twórczością nominowanego do nagrody Goncourtów kosmopolitycznego pisarza Fouada Laroui czy zdobywczyni nagrody Goncourtów w 2016 roku Leïli Slimani.

Na koniec pozwolę sobie zapytać na czym polega - w opinii Pani Profesor - fenomen literatury frankofońskiej i jej popularność, której znakiem jest choćby mnogość przekładów na język polski rozmaitych dzieł autorów francuskojęzycznych wywodzących się spoza Francji, w tym twórców maghrebskich? Dość wspomnieć: Hizam znaczy pas Ahmeda Abodehmana, Ludożerców Mahiego Binebine, O mojej matce, Dziecko piasku, Święta noc, To oślepiające, nieobecne światto Tahara Ben Jellouna, Przebudź się, matko Drissa Chraibiego, Oran martwy język Assia'i Djebar, wreszcie - cały wachlarz utworów ukrywającego się pod pseudonimem literackim „Yasmina Khadra” Mohammeda Moulessehoula Owieczki Pana, O czym marza wilki, Jaskótki z Kabulu, Kuzynka K, Zamach, Co dzień zawdzięcza nocy, Aniołowie umierają od naszych ran.

M.Z.-C.: Francuskojęzyczna literatura Maghrebu zyskuje coraz większe grono czytelników w Polsce. Być może dlatego, że nie odwraca się od problemów dzisiejszego świata, wyraża niepokoje współczesności. Okazuje się interesująca dla polskiego czytelnika, ponieważ przedstawia zjawiska powszechnie znane, obecne w mediach, takie jak np. fundamentalizm religijny, konflikty zbrojne, imigrację, rasizm, ale czyni to $\mathrm{w}$ znacznie szerszej perspektywie niż ta, do której przyzwyczaja nas „dyskurs większości”. Dąży do ujawnienia prawdy, poszukuje zrozumienia przede wszystkim w odniesieniu do spraw trudnych do rozwiązania, często bolesnych. Jest przepojona ludzką solidarnością, humanitaryzmem, otwarta na Inność. Okazuje się bardzo atrakcyjna dla polskiego czytelnika: bowiem pozostaje związana z bliską mu tradycją prozy francuskiej, a zarazem rozpościera przed nim nie do końca znany świat Orientu. Jest prawdziwym pomostem kulturowym, miejscem spotkania, dialogu, różnorodności. Równocześnie to wzrastające zainteresowanie Maghrebem i literaturą frankofońską zdaje się wskazywać, że czytelnik pragnie powrotu do literatury, która niejako stanie się podróżą: poprowadzi przez współczesność, odkrywając jej ciemne zakamarki: świat więzienny w cytowanej przez Panią powieści To oślepiające, nieobecne 
światto Tahara Ben Jellouna (opartej na autentycznej relacji więźnia politycznego z epoki Hassana II), koszmar afrykańskich uchodźców w Ludożercach Binebine’a czy terror talibów w Jaskótkach z Kabulu. Czytelnik frankofońskiej literatury maghrebskiej zdaje się podzielać opinię sygnatariuszy wspomnianego już dzisiaj manifestu Pour une littérature-monde en francais: poszukuje książki, która nie będzie oferować ucieczki od rzeczywistości, przeciwnie, pomoże zrozumieć współczesny świat.

Dziękuję Pani za rozmowę. Mam nadzieję, że udało nam się w prezentowanych tu rozważaniach nie tylko nawiązać do zjawiska podróży jako jednego $\mathrm{z}$ istotnych motywów frankofońskiej literatury Maghrebu, ale także - a może przede wszystkim przedstawić polskiemu czytelnikowi szeroką panoramę życia literackiego Arabskiego Zachodu, charakterystyczne tendencje i nurty tego piśmiennictwa oraz najwybitniejszych twórców i sylwetki kreślonych przez nich bohaterów. 